Jurnal Indonesia Sosial Teknologi: p-ISSN: 2723 - 6609

e-ISSN : 2548-1398

Vol. 1, No. 4 November 2020

\title{
ANALISA LAJU PERTUMBUHAN SILICA SCALING PADA PIPA AIR KONDENSAT SCRUBBER UNIT 5 DI INDUSTRI GEOTHERMAL
}

\author{
Puji Astuti Ibrahim, Ahda Nur Fajri
}

Teknik Kimia Akademi Minyak dan Gas Balongan

Email : pujiastutiibrahim32@gmail.com, ahdanurf@gmail.com

\begin{abstract}
The geothermal industry is an eco-friendly and renewable alternative energy, besides of many advantages of geothermal energy there are also weakness, one of which is scale. The type of scale found in PLTP Kamojang is silica. Silica scaling is a mineral that has the least composition but has the highest hardness, therefore it is necessary to analyze the possibility of silica scaling deposition and how fast the silica grows and how to overcome it. In the analysis for 8 days, it was found that the greatest precipitation was 0,00167 in3/year or 0,274 cm3 / year, this amount was still under the standard of the company. Considering that scaling can inhibit production in industry, scaling growth must be minimized by maintaining mineral solubility by spraying water on the scrubber and also by adding $\mathrm{HCl}$ inhibitors.
\end{abstract}

Keywords: Minerals, Silica Growth, Silica Scaling, Silica Saturation Index

\begin{abstract}
Abstrak
Tujuan penelitian di industri panas bumi ini merupakan sumber energi alternatif yang ramah lingkungan serta dapat di perbaharui, selain dengan banyaknya keunggulan dari energi panas bumi terdapat juga kekurangan salah satunya scale. Jenis scale yang terdapat pada PLTP Kamojang adalah silka. Metode penelitian Silika scaling merupakan jenis mineral yang paling sedikit komposisinya tetapi memiliki kekerasan paling tinggi, karena itu perlu di lakukan analisis tentang kemungkinan terjadinya pengendapan silika scaling dan berapa cepat pertumbuhan silika dan bagai mana cara menanggulanginya. Hasil analisi semala 8 hari di temukan pengendapan paling besar $0,00167 \mathrm{in}^{3} /$ tahun atau $0,274 \mathrm{~cm}^{3} /$ tahun, jumlah tersebut masih di bawah standar dari perusahaan. Mengingat scaling dapat menghambat produksi pada industri maka scaling harus di minimalisir pertumbuhannya dengan cara menjaga kelarutan mineral dengan menyemprotkan air pada scrubber dan juga dengan menambahkan inhibitor $\mathrm{HCl}$.
\end{abstract}

Kata Kunci: : Mineral, Pertumbuhan Silika, Silika Scaling, Silica Saturation Index 


\section{Pendahuluan}

Masalah ketersediaan energi menjadi sebuah permasalahan di Indonesia. Sebagaimana diketahui saat ini cadangan minyak di Indonesia sudah semakin menipis, sehingga dibutuhkan energi alternatife sebagai penunjang kebutuhan energi Indonesia. Salah satu jenis energi terbarukan yang berpotensi di Indonesia adalah energi panas bumi. Panas bumi adalah bentuk energi terbarukan yang menghasilkan sedikit emisi gas rumah kaca dan dapat memberikan kestabilan dan keamanan energi.

Meskipun pemanfaatan energi panas bumi memiliki resiko yang kecil terhadap lingkungan bukan berarti tidak memiliki masalah di dalam pemanfaatannya, masalah yang sering di jumpai pada PLTP adalah korosi. Korosi yang terjadi pada peralatan industri panas bumi kali ini adalah scaling. Scaling merupakan pengendapan yang terjadi pada peralatan industri yang biasanya terletak pada turbin dan pemipaan, pada umumnya terdapat kandungan silika pada endapan scaling.

Peralatan industri panas bumi yang terlewati oleh mineral yang terbawa oleh fluida dengan jumlah yang banyak dan waktu yang lama akan membuat mineral tersebut terendapkan pada peralatan industri, pengendapan yang terjadi pada peralatan industri diakibatkan karena perbedaan tekanan, $\mathrm{pH}$, salinitas dan temperature pada fluida panas bumi, oleh karena itu perlu di lakukan kajian yang membahas tentang terjadinya silika scaling pada proses pemanfaatan panas bumi, di karenakan silika scaling merupakan salah satu endapan yang mempunyai tingkat kekerasan paling tinggi.

\section{Energi Panas Bumi/ Geothermal}

Panas bumi merupakan sumber daya panas alami yang terdapat di dalam bumi, merupakan hasil interaksi antara panas yang dipancarkan batuan panas (magma) dan air tanah yang berada disekitarnya, dimana cairan yang terpanasi terperangkap di dalam batuan yang terletak dekat permukaan sehingga secara ekonomis dapat dimanfaatkan. Daerah panas bumi (geothermal area) atau medan panas bumi (geothermal field) adalah suatu daerah dipermukaan bumi dalam batas tertentu dimana terdapat energi panas bumi dalam suatu kondisi hidrologi-batuan tertentu atau disebut sistem panas bumi. Energi panas bumi umumnya banyak terdapat di sekitar gunung berapi baik yang masih aktif maupun yang sudah mati/istirahat (abandon). Dalam pemanfaatan sistem panas bumi dapat di gunakan berbagai macam metode pada sumur tersebut berdasarkan karakteristik dari fluida yang di hasilkan (Setyaningsih, 2014).

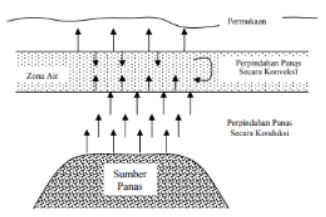

Gambar 1. Proses terjadinya perpindahan panas 


\section{Pemipaan}

Dalam produksi panas bumi pipa merupakan teknologi dalam mengalirkan fluida seperti minyak, gas atau air dalam jumlah yang sangat besar dan jarak yang jauh melalui laut dan daerah tertentu. Pipeline merupakan sarana transportasi diam yang berfungsi untuk mendistribusikan fluida baik dalam bentuk liquid maupun gas. (Saptadji, 2001).

Sementara itu, risiko didefinisikan sebagai kombinasi antara kemungkinan terjadinya kegagalan (probability of failure) dan konsekuensi terjadinya kegagalan. Karena medan yang di lalui saluran pipa sangat beragam, mulai dari laut dataran rendah, lembah, dan didalam tanah maka dalam pengoperasiannya akan banyak di temukan berbagai macam masalah seperti korosi (corrosion) maupun retak atau terputus. Keretakan merupakan persoalan yang harus diperhatikan karena akibat yang ditimbulkan yaitu ledakan dan kebocoran yang bisa mempengaruhi kehidupan sosial dan kerugian yang sangat besar.(El Fandari, Daryanto, \& Suprayitno, 2014).

Dalam pembuatan suatu kontruksi diperlukan material sesuai dengan standard yang digunakan. Sebagai contoh dalam pembuatan kontruksi sebuah instalasi proses produksi minyak dan gas alam diperlukan material yang kuat untuk menerima beban dan tegangan yang diterima oleh material. Material juga harus elastis agar pada saat terjadi pembebanan standar atau berlebih tidak mengalami patah, Salah satu contoh material yang banyak digunakan untuk kontruksi instalasi proses produksi minyak dan gas alam adalah baja karbon.

Baja merupakan paduan yang sebagian besar terdiri dari unsur besi dan karbon $0.25 \%$ - 1,7\%. Selain itu baja juga mengandung unsur-unsur lain seperti Sulfur (S), Fosfor (P), Silikon (Si), Mangan (Mn), dan Vanadium. Baja dibagi menjadi 3 (tiga) kategori yaitu :

a. Baja Karbon Rendah Baja karbon rendah merupakan baja dengan kandungan unsur karbon dalam struktur baja kurang dari 0,25\% C, Baja karbon rendah memiliki ketangguhan aus yang rendah. Baja ini tidak dapat dikeraskan karena kandungan karbonnya tidak cukup untuk membentuk struktur martensit.

b. Baja Karbon Sedang Baja karbon sedang merupakan baja karbon dengan persentase kandungan karbon pada besi sebesar 0,25\% C - 0,55\% C. Baja karbon sedang memiliki kelebihan bila dibandingkan dengan baja karbon rendah, baja karbon sedang memiliki sifat mekanis yang lebih kuat dengan tingkat kekerasan yang lebih tinggi dari pada baja karbon rendah. Besarnya kandungan karbon yang terdapat dalam besi memungkinkan baja untuk dapat dikeraskan dengan memberikan perlakuan panas (heat treatment) yang sesuai.

c. Baja Karbon Tinggi Baja karbon tinggi adalah baja yang memiliki kandungan karbon sebesar $0,55 \% \mathrm{C}-1,7 \% \mathrm{C}$. Baja karbon tinggi memiliki sifat tahan panas, kekerasan serta kekuatan tarik yang sangat tinggi akan tetapi memiliki keuletan yang lebih rendah sehingga baja karbon ini menjadi lebih getas.

Dalam penyaluran steam dalam industri panas bumi, pipa yang di gunakan sering kali mengalami kerusakan yang di akibakan berbagai masalah, salah satunya adalah scaling. (Antara, 2017) 


\section{Scaling}

Scaling didefinisikan sebagai pembentukan endapan atau kerak yang berasal dari mineral garam terlarut dalam air pada suatu media kontak tertentu. Salah satu penyebab terbentuknya scaling adalah adanya kandungan silika $\left(\mathrm{SiO}_{2}\right)$ yang terkandung dalam steam. Sifat-sifat yang mempengaruhi konsentrasi kelarutan silika dalam pembentukan scaling adalah temperature, kadar garam , dan nilai keasaman $(\mathrm{pH})$. Ketika terjadi perubahan tekanan, temperature, dan $\mathrm{pH}$ pada suatu sistem, keseimbangan ion-ion yang terkandung akan melebihi kelarutannya, sehingga terbentuk suatu endapan.

Scaling umumnya dapat dijumpai pada pipa antara daerah wellhead dengan separator, flasher, pipa liquid setelah separator (yang kemudian dibuang ke kolam penampungan) dan sumur reinjeksi sehingga dapat mengganggu proses operasional pemanfaatan geothermal pada pipelines, turbin, maupun sumur injeksi. Hal tersebut terjadi karena scaling dapat mengakibatkan penyumbatan pipa, sehingga mengurangi laju aliran dan dampak jangka panjangnya harus dilakukan penggantian. Oleh karena itu kajian tentang potensi silika scaling sangat diperlukan pada operasi lapangan panas bumi. Upaya pencegahan yang seringkali dilakukan adalah dengan menginjeksi zat kimia pengontrol scale (inhibitor scale), baik pada sumur maupun pada pipa-pipa dan peralatan produksi. Zat kimia tersebut bekerja dengan cara menjaga partikel pembentuk scale tetap dalam larutan, sehingga diharapkan tidak terjadi pengendapan. Hal ini dapat terjadi karena inhibitor bekerja untuk mencegah terbentuknya reaksi polimerisasi silika yang disebabkan penurunan kelarutan silica (PERMANA, 2017).

\section{Pencegahan Terjadinya Silika Scaling}

Scale inhibitor adalah bahan kimia yang menghentikan atau mencegah terbentuknya scale bila ditambahkan pada konsentrasi yang kecil pada air. Penggunaan bahan kimia ini sangat menarik, karena dengan dosis yang sangat rendah dapat mencukupi untuk mencegah scale dalam periode waktu yang lama. Mekanisme kerja scale inhibitor ada dua, yaitu:

1. Scale inhibitor dapat teradsorpsi pada permukaan kristal scale pada saat mulai terbentuk. Inhibitor merupakan kristal yang besar yang dapat menutupi kristal yang kecil dan menghalangi pertumbuhan selanjutnya.

2. Dalam banyak hal bahan kimia dapat dengan mudah mencegah menempelnya suatu partikel-partikel pada permukaan padatan (Aziz \& Ola, 2019).

Kelompok scale inhibitor antara lain: inorganik poliphospat, inhibitor organik, phosponat, ester phospat, dan polimer. Inorganik poliphospat adalah padatan inorganik non-kristalin. Senyawa ini jarang digunakan dalam operasi perminyakan. Kerugiannya adalah merupakan padatan dan bahan kimia ini mudah terdegradasi dengan cepat pada $\mathrm{pH}$ rendah atau pada temperature tinggi. Inhibitor organik biasanya dikemas sebagai cairan konsentrat dan tidak dapat dipisahkan sebagai bahan kimia stabil. Ester phospat 
merupakan scale inhibitor yang sangat efektif tetapi pada temperature diatas $175^{\circ} \mathrm{C}$ dapat menyebabkan proses hidrolisa dalam waktu singkat. Phosponat merupakan scale inhibitor yang baik untuk penggunaan pada temperature diatas $350 \mathrm{~F}$. Sedangkan polimer seperti akrilat dapat digunakan pada temperature diatas $350^{\circ} \mathrm{C}$. (Habibi, Busmairizal, \& Rizal, 2012)

\section{Pemilihan Inhibitor}

Beberapa hal yang perlu diperhatikan dalam pemilihan jenis inhibitor untuk mendapatkaIl efektifitas kerja inhibitor yang baik adalah sebagai berikut:

1. Jenis scale, dengan diketahuinya komposisi scale, dapat dilakukan pemilihan scale inhibitor yang tepat.

2. Kekerasan scale.

3. Temperature, secara umum, inhibitor berkurang keefektifannya apabila temperature meningkat.

4. Setiap inhibitor mempunyai batas maksimum temperature operas agar dapat berfungsi dengan baik.

5. $\mathrm{pH}$, kebanyakan scale inhibitor konvensional tidak efektif pada $\mathrm{pH}$ rendah.

6. Kesesuaian bahan kimia, scale inhibitor yang digunakan harus sesuai dengan bahan kimia lain yang juga digunakan untuk kepentingan operasi seperti corrosion inhibitor. Beberapa scale inhibitor ada yang bereaksi dengan kalsium, magnesium atau barium membentuk scale pada konsentrasi yang tinggi.

7. Padatan terlarut, semakin banyak padatan terlarut maka semakin tinggi konsentrasi inhibitor yang digunakan.

8. Kesesuaian dengan kondisi air, kandungan ion-ion kalsium, barium, dan magnesium yang ada dalam air akan menyebabkan terjadinya reaksi dengan beberapa jenis inhibitor sehingga menimbulkan masalah baru yaitu terbentuknya endapan. Sehingga jenis inhibitor harus dipilih sesesuai mungkin.

lklim, setiap inhibitor mempunyai titik lebur tertentu dan cara menginjeksikan ke dalam sistem, sehingga untuk menghindari terjadinya pembekuan ataupun perubahan komposisi dari inhibitor (Wibowo, 2015).

\section{Jenis Inhibitor}

Beberapa Jenis Scale Inhibitor :

1. Hidrokarbon diperlukan sebagai pelarut hidrokarbon digunakan untuk menghilangkan minyak, parafin, atau asphaltic materials yang menutupi scale yang terbentuk, karena apabila digunakan asam sebagai penghilang scale maka asam ini tidak akan bereaksi dengan scale yang tertutupi oleh minyak (oil coated scale), oleh sebab itu minyak harus dihilangkan terlebih dahulu dari scale dengan menggunakan hidrokarbon.

2. Asam klorida adalah bahan yang banyak digunakan untuk membersihkan scale yang telah terbentuk. Bahan ini dapat digunakan pada berbagai kondisi. Asam klorida digunakan dengan konsentrasi 5\%, 10\%, atau $15 \% \mathrm{HCl}$. 
3. Inorganic converters biasanya merupakan suatu karbonat atau hidroksida yang akan bereaksi dengan kalsium sulfat dan membentuk acid soluble calcium carbonate. Kemudian diikuti dengan penambahan asam klorida untuk melarutkan karbonat atau kalsium hidroksida yang terbentuk.

4. Organic converters seperti natrium sitrat, potassium asetat sering digunakan. Reaktan ini akan bereaksi dengan scale kalsium sulfat, sehingga scale akan menjadi lebih lunak dan mudah dibersihkan dengan melewatkan air.

5. Natrium Hidroksida Larutan $10 \%$ natrium hidroksida dapat melarutkan hingga $12,5 \%$ berat dari scale kalsium karbonat. (Habibi et al., 2012).

Dalam sistem pemipaan panas bumi, scaling yang terjadi akan menimbulkan korosi pada pipa tersebut. Korosi adalah penurunan mutu logam akibat reaksi elektro kimia dengan lingkungannya. Korosi atau pengkaratan yang merupakan fenomena kimia pada bahan - bahan logam yang pada dasarnya merupakan reaksi logam menjadi ion pada permukaan logam yang kontak langsung dengan lingkungan berair dan oksigen. Contoh yang paling umum, yaitu kerusakan logam besi dengan terbentuknya karat oksida. Dengan demikian, korosi menimbulkan banyak kerugian. Korosi pada logam melibatkan proses anodik, yaitu oksidasi logam menjadi ion dengan melepaskan elektron ke dalam (permukaan) logam, dan proses katodik yang mengkonsumsi elektron tersebut dengan laju yang sama. (Utomo, 2009)

\section{Hal-hal yang dapat menyebabkan terjadinya Korosi}

Terdapat beberapa factor yang dapat enyebabkan korosi, yaitu :

1. Faktor Gas Terlarut.

- Oksigen $\left(\mathrm{O}_{2}\right)$

- Karbondioksida $\left(\mathrm{CO}_{2}\right)$

2. Faktor Temperature

3. Faktor $\mathrm{pH}$

4. Faktor Bakteri Pereduksi atau Sulfat Reducing Bacteria (SRB)

5. Faktor Padatan Terlarut

- Klorida $(\mathrm{Cl})$

- Karbonat $\left(\mathrm{CO}_{3}\right)$

- Sulfat $\left(\mathrm{SO}_{4}\right)$, (Sidiq, 2013)

\section{Metode Penelitian}

1. Untuk menenentukan silika yang terbentuk menggunakan persamaan silica saturated index (SSI) :

$$
S S I=\frac{\operatorname{SiO} 2(\text { Calc })}{\operatorname{SiO2}(\text { Theo })}
$$

Dengan perhitungan :

$$
\mathrm{SiO}_{2}(\mathrm{Theo})=10^{\wedge}\left\{-\frac{731}{T(K)}+4,52\right\} \quad \text { dan } \quad \mathrm{SiO}_{2}(\mathrm{Calc}) \mathrm{WH}=\mathrm{SiO} 2: \mathrm{W}
$$

Keterangan : 
- $\quad$ Nilai 731 = Temperature fluida paling tinggi dalam kelvin

- $\mathrm{T}(\mathrm{K}) \quad=$ Temperature scrubber dalam kelvin

- $\quad$ Nilai 4,52 = pH rata-rata fluida

- Water Fraction = Jumlah air dalam fluida

- $\quad$ SSI > 1, fluida dalam kondisi supersaturated dan scaling dimungkinkan terjadi.

- $\quad \mathrm{SSI}=1$, fluida dalam kondisi saturated.

- $\quad$ SSI < 1, fluida dalam kondisi undersaturated, sehingga tidak mungkin terjadi pengendapan.

2. Untuk menentukan seberapa cepat laju penebalan silika scaling, maka dapat di hitung dengan persamaan

$$
\text { St }=\frac{[\text { Calculat }- \text { Teoritis }]}{1743 \times \rho s i l i c a} \times 365
$$

Keterangan :

- $S t^{\cdot} \quad=$ Laju penebalan scaling (inch/tahun)

- $\operatorname{\rho silica}=$ Densitas silika $=2,65 \mathrm{~g} / \mathrm{in}^{3}$

- $365=$ Jumlah hari dalam satu tahun

- $1743=$ Titik lebur $\mathrm{SiO}_{2}$

(Villaseñor,2011)

\section{Hasil dan Pembahasan}

\section{Faktor - faktor tebentuknya silica scaling}

Pada proses pembentukan silika scaling, faktor-faktor yang mempengaruhinya adalah temperature, $\mathrm{pH}$ dan kadar garam. Pada industri panas bumi kamojang, faktor yang membuat pembentukan scaling adalah temperature dan $\mathrm{pH}$ di karenakan tidak ada pengujian untuk kadar garam pada air pembuangan scrubber. Untuk nilai $\mathrm{pH}$ pada steam di lakukan pengamatan pada kepala sumur dan di dapatkan nilai $\mathrm{pH}$ 5,2 dan untuk temperature pada pipa air scrubber di dapatkan nilai $149^{\circ} \mathrm{C}$. Pada kasus yang terjadi di pipa air kondensat scrubber unit 5, scall di akibatkan oleh perbedaan temperature yang sangat tinggi yang mengakibatkan jumlah air lebih sedikit di bandingkan mineral yang terbuang. Hal ini mengakibatkan mineral terendapkan pada dinding-dinding pipa yang dapat menyebabkan penyempitan diameter dalam pipa serta memungkinkan terjadinya korosi

\section{Pencegahan dan Pengendalian terjadinya Silica Scaling}

Dalam terbentuknya silika scaling, proses pembentukan dapat di cegah dan di kendalikan pertumbuhannya, pada industri geothermal ini dengan proses pencegahan dan pengendaliannya menggunakan beberapa metode, yaitu :

- Pencegahan :

Pencegahan yang di lakukan dengan menambahkan $\mathrm{HCl}$ pada pipa pembuangan air dari scrubber, proses penambahan $\mathrm{HCl}$ pada pipa di lakukan secara manual dengan jangka 
waktu 1 bulan yang di maksudkan untuk menjaga dinding dalam bagian pipa agar tidak rusak yang diakibatkan oleh larutan $\mathrm{HCl}$ yang bersifat asam.

- Pengendalian :

Proses pengendalian terhadap silica scaling pada pipa dilakukan saat terjadi overhaul atau perbaikan menyeluruh pada peralatan industri. Proses pengendalian dilakukan dengan cara mencabut pipa yang terdiri dari 2 bagian, lalu menyikat dinding dalam pipa menggunakan sikat kawat, penyikatan dilakukan pada bagian yang terdapat scall dengan sangat hati-hati supaya tidak membuat dinding dalam pipa tergores oleh kawat yang akan mengakibatkan timbulnya masalah lain pada pipa.

\section{Menghitung dan Menganalisis Pertumbuhan Silica Scaling}

Dari data yang di dapatkan selama 8 hari maka didapatkan nilai SiO2nya yang tertera pada table dibawah ini:

Tabel 1 Nilai Water Fraction (WF) dan Temperature Scrubber

\begin{tabular}{|c|c|c|c|c|}
\hline No. & Tanggal & $\mathbf{T}(\mathbf{K})$ & $\mathbf{W F}$ & $\begin{array}{c}\text { Nilai SiO } \\
(\mathbf{p p m})\end{array}$ \\
\hline 1 & $20 / 01 / 2020$ & 240,42 & $100 \%$ & $50,43 \mathrm{ppm}$ \\
\hline 2 & $21 / 01 / 2020$ & 240,51 & $100 \%$ & $50,78 \mathrm{ppm}$ \\
\hline 3 & $22 / 01 / 2020$ & 240,71 & $100 \%$ & $50,71 \mathrm{ppm}$ \\
\hline 4 & $23 / 01 / 2020$ & 239,76 & $100 \%$ & $50,31 \mathrm{ppm}$ \\
\hline 5 & $24 / 01 / 2020$ & 239,57 & $100 \%$ & $50,38 \mathrm{ppm}$ \\
\hline 6 & $25 / 01 / 2020$ & 239,83 & $100 \%$ & $50,86 \mathrm{ppm}$ \\
\hline 7 & $26 / 01 / 2020$ & 239,85 & $100 \%$ & $50,81 \mathrm{ppm}$ \\
\hline 8 & $27 / 01 / 2020$ & 239,78 & $100 \%$ & $50,41 \mathrm{ppm}$ \\
\hline
\end{tabular}

Data pada table 1 merupakan data hasil kalkulasi selama satu hari dan di dapatkan nilai temperature scrubber paling tinggi pada tanggal 22/01/2020 sebesar $240,71^{\circ} \mathrm{K}$ dan di dapatkan jumlah WF (Water Fraction) $100 \%$ dikarenakan pada pipa pembuangan hanya terdapat air hasil kondensasi pada scrubber.

\section{Menghitung Nilai SSI}

Untuk mengukur nilai SSI ( Silica Saturation Indeks )

maka bisa menggunakan persamaan :

$$
\mathrm{SSI}=\frac{\operatorname{SiO} 2(\text { Calc })}{\text { SiO2(Theo })}
$$

a. Menentukan Nilai SiO2 Teoritis

Contoh perhitungan pada tanggal 20/01/2020

- $\left.\mathrm{SiO}_{2}(\mathrm{Theo})=10^{\{-} \frac{731}{T(K)}+4.52\right\}^{-731}$

- $\mathrm{SiO}_{2}(\mathrm{Theo})=10^{\left\{-\frac{731}{240,42}+4.52\right\}}$

- $\mathrm{SiO}_{2}(\mathrm{Theo})=30,2$

\section{b. Menentukan Nilai SiO2 Kalkulasi}


Contoh perhitungan pada tanggal 20/01/2020

- $\mathrm{SiO}_{2}(\mathrm{Calcu})=\mathrm{SiO}_{2}: \mathrm{WF}$

- $\mathrm{WF}=100 \%$

- $\mathrm{SiO}_{2}(\mathrm{Calcu})=50,43: 1$

- $\mathrm{SiO}_{2}(\mathrm{Calcu})=50,43$

Setelah ditemukan nilai Teoritis dan nilai Kalkulasinya, maka selanjutnya menghitung nilai SSI, menghasilkan :

- $\mathrm{SSI}=\frac{50,43}{30,2}$

- SSI $=1,67$

Tabel 2 Hasil Perhitungan SSI

\begin{tabular}{|c|c|c|c|c|}
\hline Tanggal & $\begin{array}{c}\mathrm{T}_{\text {Scrubber }} \\
(\mathrm{K})\end{array}$ & $\mathrm{WF}$ & $\begin{array}{c}\mathrm{SiO}_{2} \\
(\mathrm{ppm})\end{array}$ & SSI \\
\hline $20 / 01 / 2020$ & 240,42 & $100 \%$ & 50,43 & 1,67 \\
\hline $21 / 01 / 2020$ & 240,51 & $100 \%$ & 50,78 & 1.68 \\
\hline $22 / 01 / 2020$ & 240,71 & $100 \%$ & 50,71 & 1,68 \\
\hline $23 / 01 / 2020$ & 239,76 & $100 \%$ & 50,31 & 1.70 \\
\hline $24 / 01 / 2020$ & 239,57 & $100 \%$ & 50,38 & 1,71 \\
\hline $25 / 01 / 2020$ & 239,83 & $100 \%$ & 50,86 & 1.71 \\
\hline $26 / 01 / 2020$ & 239,85 & $100 \%$ & 50,81 & 1,72 \\
\hline $27 / 01 / 2020$ & 239,78 & $100 \%$ & 50,41 & 1,70 \\
\hline
\end{tabular}

Dari hasil perhitungan silica saturation index di dapatkan nilai SSI yang beraneka ragam setiap harinya, dan di dapatkan nilai tertinggi 1,72 pada tanggal

26/01/2020.

\section{Menghitung Laju Pertumbuhan Silika Scaling}

Contoh perhitungan pada tanggal 20/01/2020

$$
\begin{aligned}
& \text { St }=\frac{[\text { Calculat }+ \text { Teoritis }]}{1743 \times \rho \text { silica }} \times 365 \text { hari/tahun } \\
& \text { St }=\frac{[0,0132+0,0076]}{1743 \times 2,65 \mathrm{~g} / \mathrm{in} 3} \times 365 \text { hari } / \text { tahun } \\
& \mathrm{St}=\frac{0,0208}{4618,95} \times 365 \text { hari } / \text { tahun } \\
& \mathrm{St}=0,00164 \mathrm{in}^{3} / \text { tahun }
\end{aligned}
$$


Tabel 3 Hasil Perhitungan Laju Pertumbuhan Silika Scaling

\begin{tabular}{|c|c|c|c|c|}
\hline Tanggal & $\begin{array}{c}\mathrm{T}_{\text {Scrubber }} \\
(\mathrm{K})\end{array}$ & $\begin{array}{c}\mathrm{SiO}_{2} \\
(\mathrm{ppm})\end{array}$ & SSI & St (in 3 /tahun) \\
\hline $20 / 01 / 2020$ & 240,42 & 50,43 & 1,67 & 0,00164 \\
\hline $21 / 01 / 2020$ & 240,51 & 50,78 & 1.68 & 0,00165 \\
\hline $22 / 01 / 2020$ & 240,71 & 50,71 & 1,68 & 0,00167 \\
\hline $23 / 01 / 2020$ & 239,76 & 50,31 & 1.70 & 0,00154 \\
\hline $24 / 01 / 2020$ & 239,57 & 50,38 & 1,71 & 0,00154 \\
\hline $25 / 01 / 2020$ & 239,83 & 50,86 & 1.71 & 0,00157 \\
\hline $26 / 01 / 2020$ & 239,85 & 50,81 & 1,72 & 0,00158 \\
\hline $27 / 01 / 2020$ & 239,78 & 50,41 & 1,70 & 0,00154 \\
\hline
\end{tabular}

Pada tabel 3 terlihat bahwa laju penebalan silika scaling beragam dengan laju penebalan paling tinggi sebesar $0,00167 \mathrm{in}^{3} /$ tahun atau $0,274 \mathrm{~cm}^{3} /$ tahun dengan rata-rata jumlah $\mathrm{SiO}_{2}$ 50,74 ppm/hari, dengan ukuran pipa air kondensat sebesar 8in.

Data hasil perhitungan dipengaruhi oleh temperature dari scrubber sehingga walaupun nilai $\mathrm{SiO}_{2}$ lebih besar pada tanggal 25 Januari 2020 tidak menjamin nilai laju penebalan scaling lebih

\section{Kesimpulan}

Dari hasil diatas dapat diambil kesimpulan :

1. Faktor-Faktor yang menyebabkan terjadinya silika scaling pada pipa air kondensat scrubber unit 5 yaitu dikarenakan perbedaan temperature yang berbeda, yang di akibatkan oleh terpisahnya uap dengan air dan mineral, air yang terbuang memiliki temperature yang rendah dan jumlah yang sedikit yang menyebabkan terjadinya silika scaling pada dinding pipa air kondensat

2. Untuk mencegah terjadinya pertumbuhan silika scaling dapat di lakukan dengan menambahkan inhibitor berupa $\mathrm{HCl}$. Selain itu dapat di lakukan dengan menjaga tingkat kelarutan zat dengan menambahkan jumlah air pada scrubber.

3. Laju pertumbuhan silika scaling paling besar terdapat pada tanggal 21 dan 22 Januari 2020 sebesar 0,167 in $/$ tahun. Dengan rata-rata jumlah $\mathrm{SiO}_{2}$ sebanyak 50,74 ppm. 


\section{Bibliograpy}

Antara, Nengah Ludra. (2017). Pencegahan Akibat Terjadinya karat pada pipa boiler (studi kasus). Logic: Jurnal Rancang Bangun Dan Teknologi, 13(3), 117.

Aziz, Amiral, \& Ola, Kornelis K. (2019). Kajian Terbentuknya Scaling pada Komponen Turbin Uap Pembangkit Listrik Tenaga Panas Bumi Skala Kecil. Jurnal Teknologi Lingkungan, 20(1), 29-36.

El Fandari, Andiesta, Daryanto, Arief, \& Suprayitno, Gendut. (2014). Pengembangan energi panas bumi yang berkelanjutan. Semesta Teknika, 17(1), 68-82.

Habibi, Romi, Busmairizal, Yerimadesi, \& Rizal, Bahrizal. (2012). Studi Inhibisi Korosi Baja Oleh Ekstrak Biji Kakao (Theobroma cacao) Dalam Medium Air Laut. Periodic, 1(1), 62-65.

PERMANA, MOCH ARIL INDRA. (2017). Kajian Potensi Silica Scaling pada Pipa Produksi Pembangkit Listrik Tenaga Panas Bumi (Geothermal). Jurnal Material Dan Energi Indonesia, 7(01), 39-43.

Saptadji, Nenny Miryani. (2001). Teknik Panas Bumi. Bandung, Penerbit ITB.

Setyaningsih, Wahyu. (2014). POTENSI LAPANGAN PANAS BUMI GEDONGSONGO SEBAGAI SUMBER ENERGI ALTERNATIF DAN PENUNJANG PEREKONOMIAN DAERAH. Jurnal Geografi: Media Informasi Pengembangan Dan Profesi Kegeografian, 11(1), 117-129.

Sidiq, M. Fajar. (2013). Analisa korosi dan pengendaliannya. Jurnal Foundry, 3(1), 2530 .

Utomo, Budi. (2009). Jenis korosi dan penanggulangannya. Kapal: Jurnal Ilmu Pengetahuan Dan Teknologi Kelautan, 6(2), 138-141.

Wibowo, Fadlan. (2015). Kajian Resiko Pipa Gas Transmisi PT. Pertamina Studi Kasus Simpang Km. 32-Palembang. Jurnal Teknik Sipil Dan Lingkungan, 3(1). 